\title{
A Ten-Year Retrospective Analysis of the Distribution, Use and Phenotypic Characteristics of the LAD2 Human Mast Cell Line
}

\author{
Arnold S. Kirshenbaum ${ }^{\mathrm{a}}$ Amy Petrik $^{\mathrm{b}}$ Rosemary Walsh ${ }^{\mathrm{b}}$ Tara L. Kirby $^{\mathrm{d}}$ \\ Sury Vepa ${ }^{d}$ Danny Wangsac Thomas Ried ${ }^{c}$ Dean D. Metcalfe ${ }^{a}$ \\ ${ }^{a}$ Laboratory of Allergic Diseases, ${ }^{b}$ Technology Transfer and Intellectual Property Office, National Institute of \\ Allergy and Infectious Diseases, and 'National Cancer Institute, National Institutes of Health, Bethesda, Md., and \\ ${ }^{\mathrm{d}}$ Office of Technology Transfer, National Institutes of Health, Rockville, Md., USA
}

\section{Key Words}

Mast cell · Allergy $\cdot$ Material transfer $\cdot$ FceR1 $\cdot$ Stem cell

factor · c-KIT

\begin{abstract}
Background: In 2003, this laboratory published an account of the human mast cell line LAD2 (Laboratory of Allergic Diseases 2 ) that expressed FcعRI, responded to recombinant human stem cell factor ( $r$ SCF) and resembled CD34+-derived human mast cells. LAD2 cells have now been distributed worldwide. To study the impact of this transfer, we analyzed the number of investigators receiving LAD2 cells and resulting publications. Methods: Records maintained in our laboratory, the Technology Transfer and Intellectual Property Office and Office of Technology Transfer, were reviewed for material transfer agreements (MTAs) and licensing agreements (LAs). Journals and impact factors were obtained from PubMed.gov by cross-referencing LAD2 and human mast cells from 2003 through November 2013. Results: Over 300 MTAs and 40 LAs were approved. LAD2 cells were shipped to over 30 countries. More than 80 papers have been published in journals with impact factors from 1.31 to 13.21 . Intended uses include the study of receptors, degranulation, and cell signaling. LAD2 cells continue to express described markers and have consistent FcER1-mediated degranula-
\end{abstract}

\section{KARGER}

E-Mail karger@karger.com

www.karger.com/iaa tion. Conclusions: Success of the LAD2 line reflects the demand for a human mast cell line in research, the uniqueness of this cell line, and that it continues to exhibit minimal variation from its original description. We hope that the awareness of the impact of this cell line on mast cell research will encourage others to develop and distribute other similar cell lines with additional characteristics so as to address the limitations of depending on the study of cultured human mast cells from tissues.

(c) 2014 S. Karger AG, Basel

\section{Introduction}

Mast cells are known to play a major role in innate and acquired immunity. Since 2003, there have been three maLAD2 (Laboratory of Allergic Diseases 2) [2] and LUVA (Laboratory of University of VirginiA) [3], available for study of human mast cell biology in lieu of primary mast cell cultures derived from bone marrow, or peripheral or cord blood. The LAD2 mast cell line most closely resembles primary human mast cell cultures due to (1) functional FceRI receptors and the ability to degranulate to immunologic stimuli, and (2) growth dependence on the presence of stem cell factor (SCF). LAD2 human mast cells jor cell lines, HMC-1 (Human Mast Cell leukemia-1) [1],
(C) 2014 S. Karger AG, Basel

$1018-2438 / 14 / 1644-0265 \$ 39.50 / 0$
Correspondence to: Dr. Arnold S. Kirshenbaum 
have been maintained in our laboratory for use and distribution worldwide following completion of either a NIHapproved Material Transfer Agreement (MTA) or Licensing Agreement (LA) in the case of for profit companies.

To determine whether completed MTAs and LAs represented successful transfer and use of cells and resulted in publications in peer-reviewed journals, we investigated the total number of agreements completed by investigators and companies, their geographic distribution and purpose of use, and publications using LAD2 cells. We also investigated whether the LAD2 cell line had retained its original properties over the past decade. As will be seen, the LAD2 cell line appears to owe its success, evident from its worldwide appeal and publications, to its consistent nature and performance in the laboratory. It is hoped that the research contributions in part dependent on the availability of this cell line will encourage others to develop and distribute similar cell lines using our approach as detailed in this report.

\section{Materials and Methods}

\section{Data Collection}

Records maintained in our laboratory, the Technology Transfer and Intellectual Property Office (TTIPO) and the Office of Technology Transfer (OTT), were reviewed for numbers and locations of non-profit investigator MTAs, and for-profit company LAs. Peer-reviewed journals and their impact factors were obtained from PubMed.gov by cross-referencing LAD2 and human mast cells. All data was expressed in Excel spreadsheet format.

\section{LAD2 Cell Studies}

LAD2 cells were developed as described and maintained in StemPro serum-free media with supplements and rhSCF [2]. Hemidepletions were performed weekly. To examine LAD2 CD surface markers, cells were incubated in $1 \times$ PBS containing $0.1 \%$ BSA and $1 \%$ milk, followed by staining with directly conjugated antibodies as described [4]. All analyses were performed on at least 10,000 cells. $\beta$-Hex release was assayed following crosslinking of FceRI as described [5]. Briefly, LAD2 cells were incubated overnight with human $100 \mathrm{ng} / \mathrm{ml}$ human myeloma IgE (BD PharMingen, San Diego, Calif., USA) biotinylated by the NIAID core facility, followed by crosslinking with $125 \mathrm{ng} / \mathrm{ml}$ streptavidin (SigmaAldrich, St. Louis, Mo., USA). $\beta$-Hex was reported as $\%$ of total cell contents released.

\section{Karyotypic Analysis}

Karyotyping of chromosomes was performed on LAD2 cells. To determine the karyotype of LAD2 cells, metaphases were harvested from $5-10 \times 10^{6}$ cells that were arrested in metaphase, using colcemid overnight, placed in hypotonic potassium chloride, and fixed in methanol and acetic acid. Analysis using spectral karyotyping and composite karyotyping was performed for studying chromosomal number and aberrations, following nomenclature rules from ISCN, 2009 (http://www.karger.com/Book/Home/244102).
Sequencing of LAD2 KIT cDNA

Total RNA was extracted from $1 \times 10^{6}$ LAD2 cells using the RNeasy Plus RNA isolation kit (Qiagen, Germantown, Md., USA) as described [6]. Approximately $1 \mu \mathrm{g}$ of total RNA was reverse transcribed using the SuperScript III First-Strand synthesis system (Invitrogen, Grand Island, N.Y., USA) with random hexamer primers. The KIT gene was PCR amplified from cDNA using Phusion high-fidelity DNA polymerase (New England BioLabs, Ipswich, Mass., USA). Overlapping KIT PCR amplification products were gel-purified and directly sequenced by Genewiz (Germantown, Md., USA). Sequencing data was analyzed using Sequencher, Version 4.5 (Softgenetics, State College, Pa., USA).

\section{Results}

MTA and LA requests are forwarded to either TTIPO or OTT, respectively, for processing and completion prior to the shipping of LAD2 cells. Handling instructions are provided when answering requests. Investigators must have necessary reagents and facilities for cell culture and for cryopreserving cells, a current shipping address and commercial carrier service prior to receiving cells. NIH departmental handling of domestic requests generally requires 2-3 weeks to complete. The process is longer for international requests, depending on import restrictions to the host country. This process has not in general been a problem for investigators, and as shown in figure 1a (blue columns), the total number of completed MTAs ranges from 20 to 40 requests per year. To date, over 300 MTAs have been documented (fig. 1a, green line). As shown in figure $1 \mathrm{~b}$ (red columns), the number of LAs now totals over 40 . Contracts are usually active for 5 years and then renewed. At least 10 companies renewed their licenses between 2007 and 2010 (fig. 1b, blue columns). LAD2 cells have been shipped worldwide, with most shipments going to laboratories within the United States, followed by Great Britain, Japan, Germany and the Netherlands (fig. 2a). North America and Europe share almost equally in the numbers of agreements successfully completed (fig. 2b).

To determine whether research involving LAD2 cells has been cited in journal publications, we surveyed PubMed by cross-referencing LAD2 and human mast cells as well as HMC-1 and LUVA cells. Research using LAD2 cells has been published in journals with impact factors ranging from 1.31 to 13.21 . Since 2005, there have been 353 publications referencing HMC- 1 cells, 84 publications for LAD2 cells, and 2 publications for LUVA cells. Paper titles and abstracts suggest that research involving LAD2 cells is broad and involves studies of mast cell degranulation, development of new compounds in- 
Fig. 1. Number of yearly MTAs, cumulative total MTAs and LAs. a Number of newly signed MTA agreements yearly (blue vertical columns), following the LAD2 cell line original publication in 2003 and total cumulative number of signed MTA agreements (green line) since 2003. b Yearly number of newly signed licenses by company research and development departments (red vertical columns). Licenses are usually renewed every 5 years and indicated by blue vertical columns.

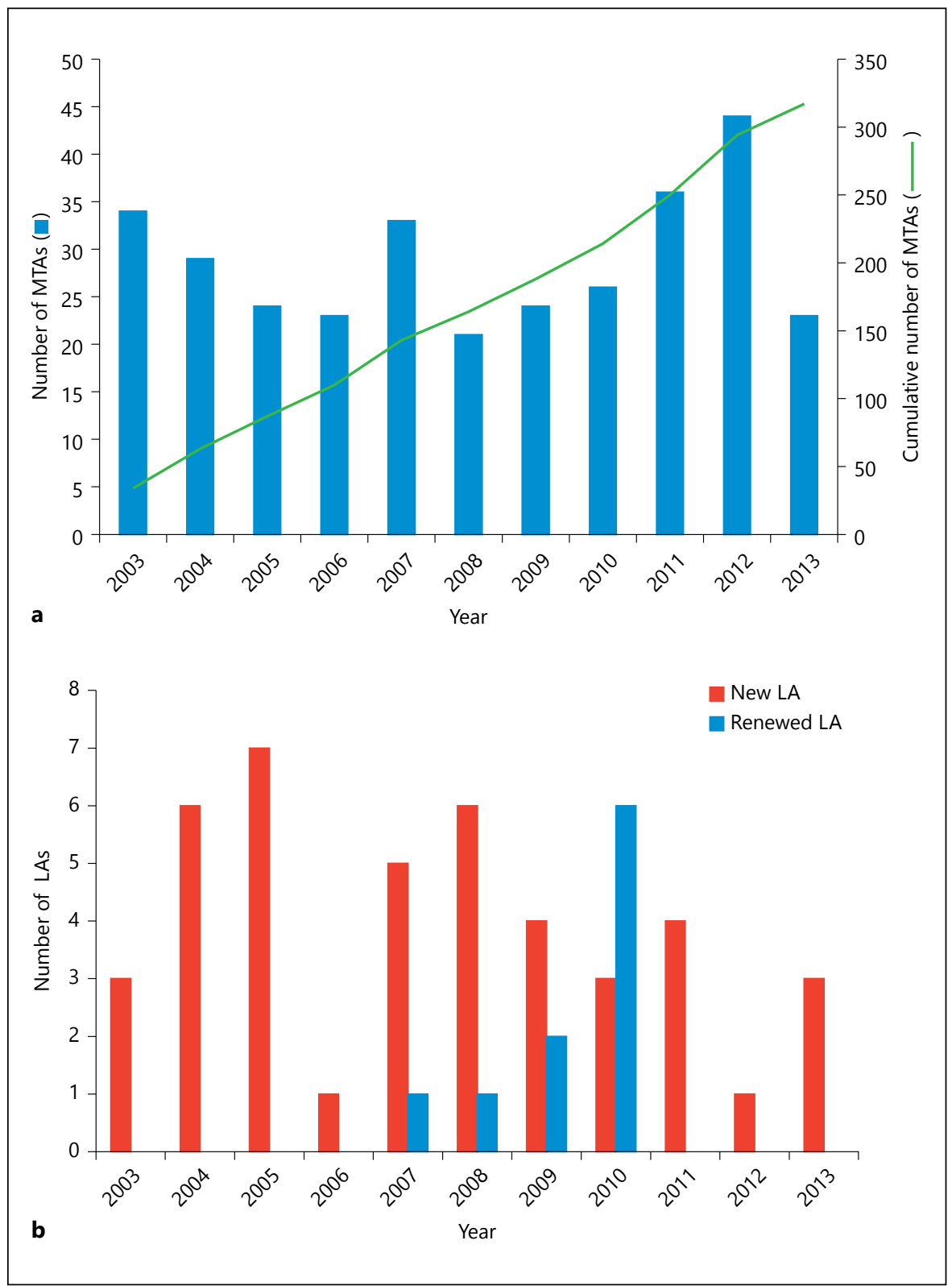

hibiting degranulation, receptor identification, examination of cell signaling and studies of genetic markers. In 2011 and 2012 combined, at least 25 journals published papers citing the use of LAD2 cells in research. Research which examined functional FceRI receptor crosslinking in addition to certain $G$ protein-coupled receptors found on LAD2 but not HMC-1 cells resulted in publications that provided the most advance onto our previous knowledge of the biology of human mast cells, and include the following: inhibition of STAT3 serine 727 phosphorylation in human mast cells leads to impaired FceRI- mediated proximal and distal signaling, as well as reduced degranulation, consistent with the absence of clinical atopy in autosomal-dominant hyper-IgE syndrome [7]; CD84 is highly expressed in human mast cells and dampens FceRI-mediated calcium mobilization and degranulation with release of IL-8 and GM-CSF after its co-crosslinking with FceRI [8]; MrgX2 is a novel GPCR on human mast cells for the antibacterial peptide cathelicidin (LL37) which is involved in innate immunity and promotes inflammation, angiogenesis, wound healing and tumor metastasis [9]; human $\beta$-defensins and LL-37 stimulate 


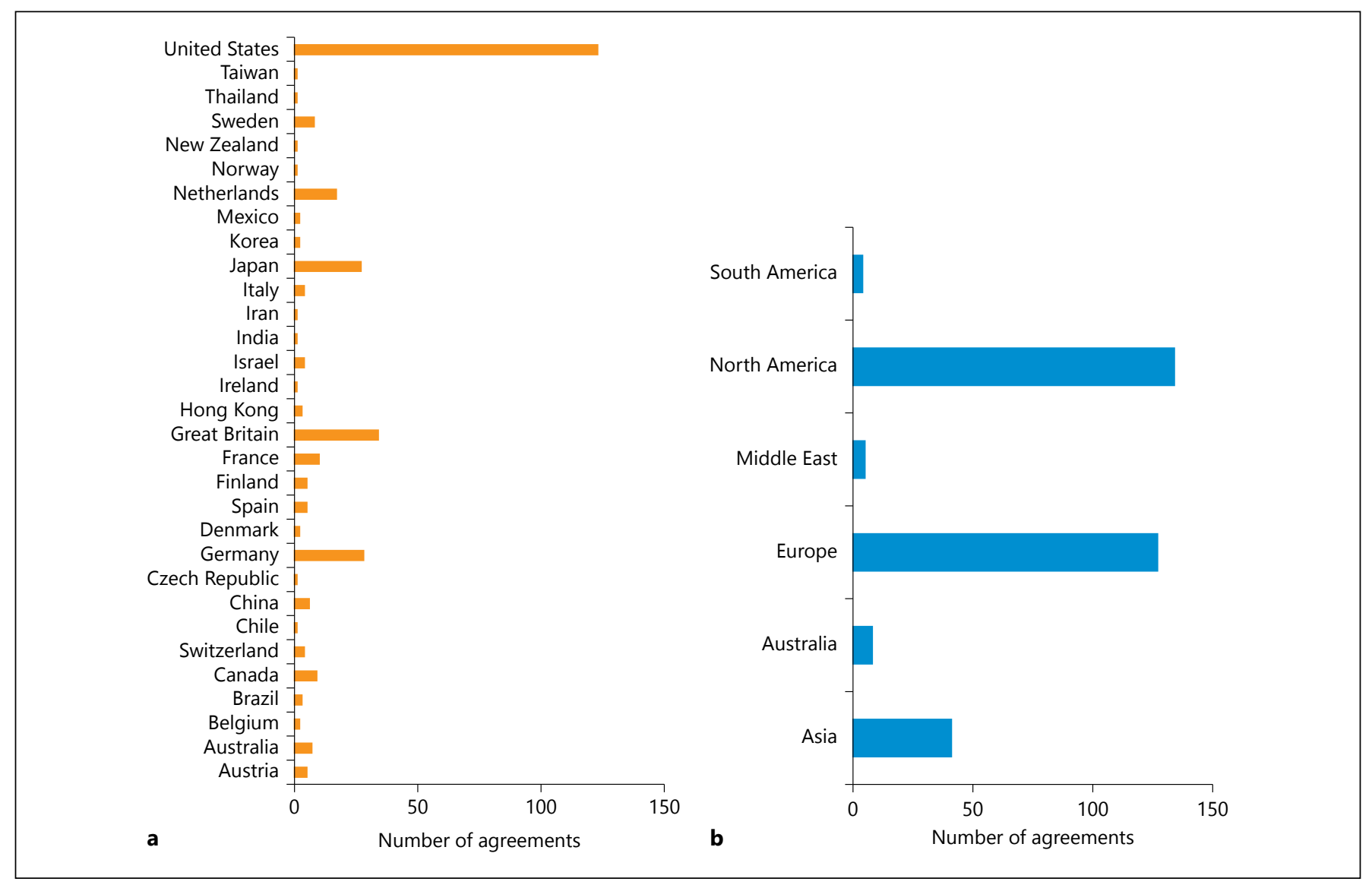

Fig. 2. Geographic distribution of signed agreements requesting LAD2 cells. a Worldwide distribution of LAD2 cells as determined by signed agreements since the original 2003 publication. b Worldwide distribution to continents of LAD2 cells as determined by signed agreements.

the secretion of a novel pruritogenic mediator IL-31 from human mast cells, suggesting a novel mechanism by which skin-derived antimicrobial peptides/proteins may contribute to inflammatory skin reactions [10], and leukotriene $(\mathrm{LT}) \mathrm{E}_{4}$, in contrast to $\mathrm{LTD}_{4}$, activates peroxisome proliferator-activated receptor- $\gamma$ and induces prostaglandin $\mathrm{D}_{2}$ generation which may help to explain how $\mathrm{LTE}_{4}$ in vivo potentiates airway hyperresponsiveness and induces bronchial eosinophilia [11]. Together, this strongly suggests that researchers, reviewers and journal editorial staff alike have accepted the LAD2 human mast cell line in the study of human mast cell biology.

One can speculate that the success investigators have enjoyed publishing with the LAD2 cell line as a research tool is due to the stability and minimal variation from characteristics originally described in 2002. To examine this possibility, LAD2 cells were tested for function, CD surface marker expression and sequencing of the c-kit proto-oncogene for the activating D816 mutation. As shown in figure $3 \mathrm{a}$, the newest lot of LAD2 cells thawed early in 2013, expanded and kept in culture according to handling instructions, gave consistently high (20-60\%) \% $\beta$-hex release, similar to the release of this cell line in studies performed in 2012 and similar to the original description of the cell line. Flow cytometry studies confirmed not only the presence of FceRI, CD4, 9, 13, 14, 22, 31, 32, 45, $64,71,103,117,132$, CD184 and CD195 as originally described, but the constitutive expression of activation markers CD63 and 203c (data not shown). Finally, complete sequencing of KIT showed two reported SNPs at amino acid positions aa529 (bp 1674) and aa531 (bp 1680), the presence of the GNNK variation [12] and as S715aa deletion polymorphism. These variations were not known in 2003. As shown in figure 3b, the major D816V activating mutation which could contribute to the cell line's immortality was not present, consistent with the original 
Fig. 3. LAD $2 \beta$-hex release and KIT sequencing. a $\beta$-Hex release from cells that were thawed, expanded and maintained throughout 2013 for distribution; cells outperformed release from cultures maintained in 2012. b Sequencing and absence of the D816V mutation in KIT from LAD2 cells cultured in 2013, as compared with sequencing of KIT first reported in 2003.

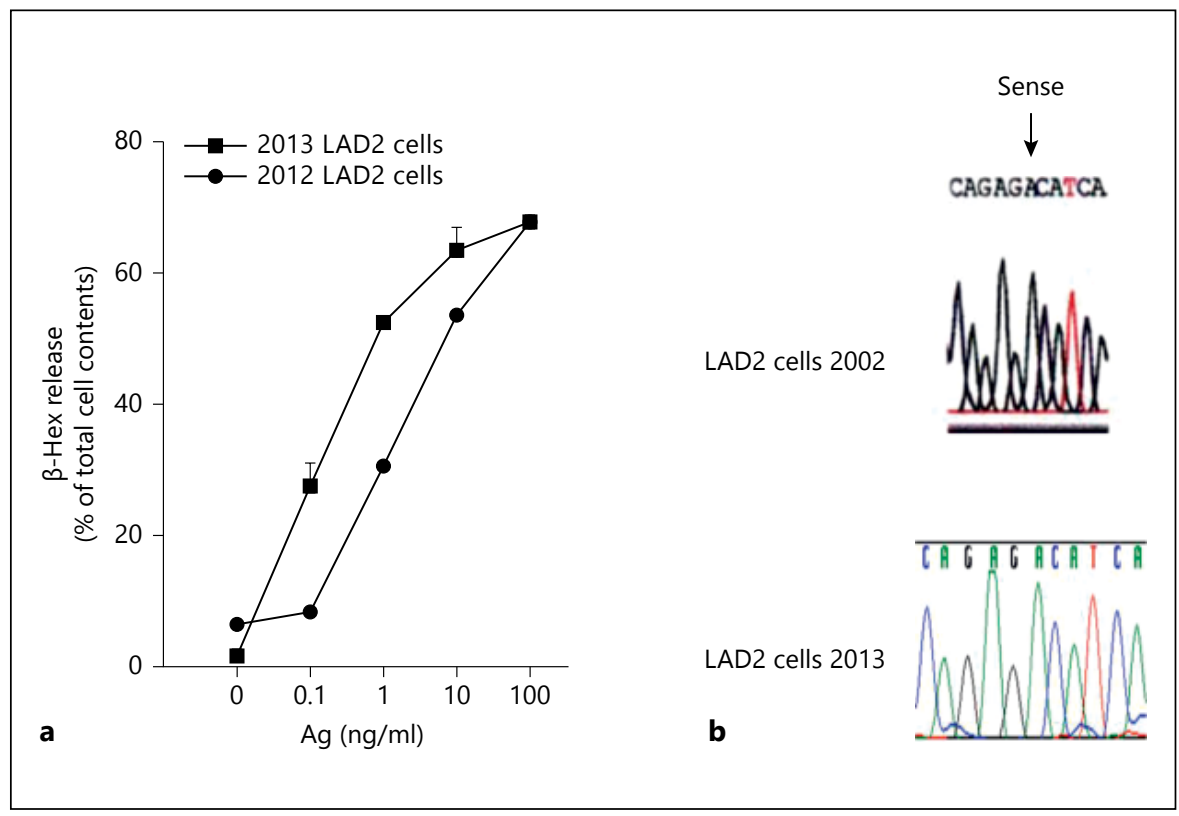

Table 1. Characteristics of human mast cell lines

\begin{tabular}{|c|c|c|c|c|c|c|c|}
\hline \multirow[t]{2}{*}{ Cell line } & \multicolumn{7}{|l|}{ Characteristics } \\
\hline & functional FceRI & SCF dependence & histamine, pg/cell & growth media & doubling time & K509I & D816V \\
\hline HMC-1.1 & no & no & 0.9 & Iscove's $/ 20 \%$ FCS & 2-3 days & + & - \\
\hline HMC-1.2 & no & no & 0.9 & Iscove's $/ 20 \%$ FCS & 2-3 days & + & + \\
\hline
\end{tabular}

2003 report and in contrast with the HMC cell line [1]. LAD2 cells were also karyotyped to determine aberrations in chromosome numbers. The composite karyotype of LAD2 cells was found to be: $47, \mathrm{XXY}+2,-21$. According to ISCN nomenclature the exact karyotype is $41-72, \mathrm{XXY}$, $-[7],+2[11],+4[2],+5[6],+7[2],+16[3],+18[2],-21[14]$ cp15. Despite this variation from the original $48, \mathrm{XXY}$ karyotype, LAD2 cells have remained remarkably stable over the past decade when cultured, frozen and thawed according to recommended handling instructions.

Comparison of the merits and weaknesses of the three existing human mast cells lines is shown in table 1. In our opinion and depending on the research interests of the investigator, a cell line closely resembling primary cultured human mast cells and with functional FceRI receptors would have an advantage for research. LAD2 and
LUVA cells both have functional FceRI receptors and LUVA cells double weekly, in contrast to LAD2 cells which have the weakness of growing more slowly and doubling every 2 weeks. HMC-1.1 and -1.2 cells double weekly, but have the weakness of lacking functional FceRI. HMC-1.2 cells have the merit of possessing the D816V mutation for study, which LAD2 and LUVA cells both lack.

\section{Discussion}

Our NIH laboratory has as its mission to conduct basic research, promote 'bench-to-bedside' research, foster progress in patient care, and to make specific resources available to other laboratories to further their research 
programs. In 2003, our laboratory published a report of the LAD2 human mast cell line which offered a unique opportunity to examine the biology of human mast cells, and in the spirit of NIH and its mission, made this tool available to researchers everywhere. The cell line has achieved remarkable worldwide success, based on the increasing number of MTAs and LAs applied for and approved (fig. 1), and has been shipped to multiple countries and continents (fig. 2). PubMed continues to document publications using LAD2 cells. Over 80 publications in peer-reviewed journals with impact factors ranging from 1.31 to 13.21 can be found dating back to 2005,2 years after LAD2 cells were first made available, on a wide array of topics including but not limited to the examination of human mast cell degranulation and inhibitors, receptors, cell signaling and genetic markers. We believe that the success investigators have enjoyed publishing with the LAD2 cell line as a research tool is due primarily to the stability and minimal variation from characteristics originally described in 2003 (fig. 3). When LAD2 cells are kept in culture for a prolonged period, reduced degranulation may result. This is why in correspondence with investigators and in our handling instructions, we urge investigators to freeze down cells as often as possible, then thaw and expand a new stock culture of cells yearly. Another phenotypic characteristic maintained over the past decade is a relatively slow dividing time, averaging 2 weeks. We believe this may account for LAD2 cells phenotypically resembling more mature CD34+-derived primary human mast cells in culture, with dependence on rhSCF for growth in addition to functional FceRI receptors and numerous intracytoplasmic granules. Furthermore, we have not been able to detect any mechanism to explain the immortality of the cell line. Thus, in the absence of the D816V mutation, we can only speculate that immortality of LAD2 cells may be due to the combination of increased levels of telomerase, as in other established tumor cell cultures, in addition to changes in spectral karyotyping. Thus, for a decade, researchers and journal editorial staff have come to accept the LAD2 human mast cell line as an invaluable research tool. We hope other similar cell lines will be made available.

\section{Acknowledgements}

The authors would like to thank Geethani Bandara and Yun Bai for their technical assistance with LAD2 cell handling and maintenance, and Dr. Hesed Padilla-Nash for interpreting the karyotype.

\section{References}

$>1$ Butterfield JH, Weiler D, Dewald G, Gleich GJ: Establishment of an immature mast cell line from a patient with mast cell leukemia. Leuk Res 1988;12:345-355

2 Kirshenbaum AS, Akin C, Wu Y, Rottem M, Goff JP, Beaven MA, Rao K, Metcalfe DD: Characterization of novel stem cell factor responsive human mast cell lines LAD 1 and 2 established from a patient with mast cell sarcoma/leukemia; activation following aggregation of FceRI or Fc $\gamma$ RI. Leuk Res 2003;27: 677-682.

-3 Laidlaw TM, Steinke JW, Tiñana AM, Feng C, Xing W, Lam BK, Paruchuri S, Boyce JA, Borish L: Characterization of a novel human mast cell line that responds to stem cell factor and expresses functional FceRI. J Allergy Clin Immun 2011;127:815-822.

-4 Radinger M, Jensen BM, Kuehn HS, Kirshenbaum AS, Gilfillan AM: Generation, isolation, and maintenance of human mast cells and mast cell lines derived from peripheral blood or cord blood. Curr Protoc Immunol 2010;90: 7.37.1-7.37.12.
5 Kuehn HS, Radinger M, Gilfillan AM: Measuring mast cell mediator release. Curr Protoc Immunol 2010;91:7.38.1-7.38.9.

6 Tomonobu I, Smrz D, Jung M-Y, Bandara G, Desai A, Smrzová S, Kuehn HS, Beaven MA Metcalfe DD, Gilfillan AM: Stem cell factor programs the mast cell activation phenotype. J Immunol 2012;188:5428-5437.

$\checkmark 7$ Siegel AM, Stone KD, Cruse G, Lawrence MG, Olivera A, Jung MY, Barber JS, Freeman AF, Holland SM, O’Brien M, Jones N, Wisch LB, Kong HH, Desai A, Farber O, Gilfillan AM, Rivera J, Milner JD: Diminished allergic disease in patients with STAT3 mutations reveals a role for STAT3 signaling in mast cell degranulation. J Allergy Clin Immunol 2013; 132:1388-1396.

8 Álvarez-Errico D, Oliver-Vila I, Ainsua-Enrich E, Gilfillan AM, Picado C, Sayós J, Martín M: CD84 negatively regulates IgE high-affinity receptor signaling in human mast cells. J Immunol 2011;187:5577-5586.

-9 Subramanian H, Gupta K, Guo Q, Price R, Ali $\mathrm{H}$ : Mas-related gene X2 (MrgX2) is a novel G protein-coupled receptor for the antimicrobial peptide LL-37 in human mast cells: resistance to receptor phosphorylation, desensitization, and internalization. J Biol Chem 2011; 286:44739-44749.
10 Niyonsaba F, Ushio H, Hara M, Yokoi H, Tominaga M, Takamori K, Kajiwara N, Saito H, Nagaoka I, Ogawa H, Okumura K: Antimicrobial peptides human $\beta$-defensins and cathelicidin LL-37 induce the secretion of a pruritogenic cytokine IL-31 by human mast cells. J Immunol 2010;184:3526-3534.

11 Paruchuri S, Jiang Y, Feng C, Francis SA, Plutzky J, Boyce JA: Leukotriene $\mathrm{E}_{4}$ activates peroxisome proliferator-activated receptor- $\gamma$ and induces prostaglandin $\mathrm{D}_{2}$ generation by human mast cells. J Biol Chem 2008;283: 16477-16487.

-12 Eunice CC, Bai Y, Bandara G, Simakovab O, Brittain E, Scott L, Dyer KD, Klion AD, Maric I, Gilfillan AM, Metcalfe DD, Wilson TM: KIT GNNK splice variants: expression in systemic mastocytosis and influence on the activating potential of the $\mathrm{D} 816 \mathrm{~V}$ mutation in mast cells. Exp Hematol 2013;41:870-881. 